\title{
Inhibition of HepG 2 cell proliferation by ursolic acid and polysaccharides via the downregulation of cyclooxygenase-2
}

\author{
LING LIU $^{1}$, JINGKAI ZHANG ${ }^{1}$, MEILING LI $^{1}$, XIAOHONG ZHANG ${ }^{1}$, JINLU ZHANG $^{1}$, \\ ZHENJING LI ${ }^{1}$, LIKUI WANG ${ }^{2}$, JIHUI WU ${ }^{3}$ and CHENG LUO ${ }^{1}$ \\ ${ }^{1}$ Key Laboratory of Food Nutrition and Safety, Tianjin University of Science and Technology, \\ Ministry of Education, School of Food Engineering and Biotechnology, Tianjin University of Science and Technology, \\ Tianjin 300457; ${ }^{2}$ Beijing Friendship Hospital, Capital Medical University, Beijing 100050; \\ ${ }^{3}$ School of Life Science, Chinese University of Science and Technology, Hefei, Anhui 230026, P.R. China
}

Received May 15, 2013; Accepted December 17, 2013

DOI: $10.3892 / \mathrm{mmr} .2014 .2059$

\begin{abstract}
Cyclooxygenase (COX)-2, a multi-functional molecule, is overexpressed in hepatocellular carcinomas. In order to understand cell proliferation and its association with COX-2 in HepG2 cells in the presence of ursolic acid (UA), viili exopolysaccharides (VEPS) and Astragalus polysaccharides (APS), the cell proliferation, superoxide dismutase (SOD) and metabolic malondialdehyde (MDA) of fatty acids, COX-2, prostaglandin E2 (PGE2), as well as apoptotic morphology and rate were investigated. The results revealed that the activities of SOD, COX-2 and PGE2 were reduced, MDA was markedly decreased, apoptotic blebs were induced, and HepG2 cells were accumulated in the G1 and sub G1/apoptotic phases in test groups. The results indicated that UA, VEPS, APS and any combination of these possess anticancer properties, particularly by downregulating COX-2 expression, which may have increased internal oxidation and triggered apoptosis together with a change in internal antioxidant response elements, leading to a reduction in cell proliferation.
\end{abstract}

\section{Introduction}

Hepatocellular carcinoma (HCC) is estimated to be the fifth most common cause of cancer-related mortality worldwide (1). Although $\sim 80 \%$ of cases are reported in developing countries, where the prevalence of hepatitis is high, HCC is one of the few types of cancer whose incidence is on the increase in developed countries $(2,3)$. Although chemotherapy has

Correspondence to: Professor Cheng Luo, Key Laboratory of Food Nutrition and Safety, Tianjin University of Science and Technology, Ministry of Education, School of Food Engineering and Biotechnology, Tianjin University of Science and Technology, 29 13th Avenue, TEDA, Tianjin 300457, P.R. China

E-mail: luo58@yahoo.com

Key words: antioxidation, anti-inflammation, COX-2, HepG2 cell, ursolic acid, polysaccharide provided significant survival benefits for HCC patients, such drugs are associated with marked tissue toxicity, and drugs or alternative therapies that target tumor cells without compromising normal tissue function are required (4). Increased concentrations of cytotoxic drugs and higher doses of radiation often fail to improve the health of liver cancer patients, and may cause resistance to apoptosis. An anticancer agent with lower toxicity that preferentially induces apoptosis in human cancer cells while creating an internal oxidative environment would be useful.

Ursolic acid (UA), a pentacyclic triterpenoid, has been identified in various natural products, such as vegetables and medicinal herbs (5). UA may inhibit cell growth and induce apoptosis in certain tumors $(6,7)$ through multiple pathways, including inhibiting DNA replication, activating caspases and downregulating anti-apoptotic genes $(8,9)$. UA specifically inhibits tumorigenesis (10), tumor progression (11), angiogenesis and tumor invasion (12).

Viili, a Nordic traditional fermented dairy product containing lactobacillus, yeast and filamentous fungi, generates large quantities of extracellular polysaccharide (EPS) (13). Viili exopolysaccharides (VEPS) reportedly have antioxidant properties (14), regulate immunity function and lower cholesterol (15). Astragalus, particularly A. membraneuse, is a common traditional Chinese medicine; its polysaccharides [or Astragalus polysaccharides (APS)] reportedly improve immune function (16), modulate the immune system and promote tumor cell apoptosis (17).

Cyclo-oxidase (COX)-2 is a key enzyme that catalyzes arachidonic acid into prostaglandins $(18,19)$. COX-2 is not expressed in the majority of organs under normal physiological conditions, but it is expressed in the majority of cancer cells (20). COX-2 is believed to inhibit cancer cell apoptosis (21), thus causing resistance to chemotherapy as COX-2 selective inhibitors suppress tumor cell proliferation and induce apoptosis (22). For these reasons, naturally derived COX-2 inhibitors have been used to study chemotherapy and chemoprevention. In this study we analyzed the synergistic effect of UA in combination with VEPS and APS, on cell proliferation, morphologic change, anti-oxidation and COX-2 expression. 
Table I. Primer sequences used for PCR.

\begin{tabular}{llllr}
\hline Genes & \multicolumn{1}{c}{ Primers (5'-3') } & Primers (5'-3') & Size (bp) & Accession \\
\hline COX-2 & TGAAACCCACTCCAAACACAG & TCATCAGGCACAGGAGGAAG & 232 & NM_000963 \\
$\beta$ - actin & AAATCTGGCACCACACCTT & AGCACTGTGTTGGCGTAGAG & 646 & NG_007992 \\
\hline
\end{tabular}

PCR, polymerase chain reaction; COX-2, cyclooxygenase-2.

\section{Materials and methods}

Chemicals. Ursolic acid ( $>99.8 \%)$ was purchased from Sigma (St. Louis, MO, USA). VEPS (>78\%) and APS (>80\%) were extracted in our laboratory. DMEM and the RevertAid First Strand cDNA Synthesis kit were purchased from Thermo Fisher Scientific Inc. (St. Louis, MO, USA). Fetal bovine serum (FBS) was purchased from Gibco (Milan, Italy). Penicillin streptomycin solution, trypsin, phosphate-buffered saline (PBS), DMSO, 3-(4,5-dimethylthiazol-2-yl)-2,5-diphenyltetrazolium bromide (MTT) and cell lysis solution were purchased from Solarbio (Beijing, China). Anti-COX-2 and anti- $\beta$-actin antibodies were purchased from Bioworld Technology (St. Louis Park, MN, USA) and goat anti-rabbit IgG antibody $(\mathrm{H}+\mathrm{L})$ was purchased from Thermo Fisher Scientific Inc. (Rockford, IL, USA). Superoxide dismutase (SOD) and malondialdehyde (MDA) test kits were purchased from Nanjing Biological Engineering (Nanjing, China), human COX-2 and human prostaglandin E2 (PGE2) enzymelinked immunosorbent assay (ELISA) kits were purchased from Bio-Swamp (Shanghai, China). The RNeasy Mini kit was purchased from Qiagen (Hilden, Germany), and the SYBR Premix Ex Taq II PCR Master Mix kit was purchased from Takara Biotechnology (Dalian, China). The West Pico Mouse IgG Detection kit was purchased from Thermo Fisher Scientific.

Cell culture and reagents. The HepG2 human HCC cell line was a gift from the Academy of Military Science (Beijing, China). Cells were maintained in DMEM medium supplemented with $10 \% \mathrm{FBS}, 100 \mathrm{U} / \mathrm{ml}$ of penicillin and $100 \mu \mathrm{g} /$ $\mathrm{ml}$ of streptomycin, and incubated in a humidified $5 \% \mathrm{CO}_{2}$ incubator at $37^{\circ} \mathrm{C}$. The culture medium was changed every two days and the cells were subcultured every fifth day. Cells in the mid-log phase were used for experiments.

Stock solutions of UA, VEPS and APS were prepared in DMSO and diluted with medium. The final concentration of DMSO was $<0.1 \%$, which demonstrated no effect on cell viability and DNA fragmentation. DMSO was also used in the controls. For all assays, the $\mathrm{HepG} 2$ cells $\left(5 \times 10^{4} / \mathrm{ml}\right)$ were treated with UA at $0.1,1,2.5,5$ or $10 \mu \mathrm{g} / \mathrm{ml}$; or VEPS or APS at $10,20,40,50$ or $100 \mu \mathrm{g} / \mathrm{ml}$, respectively. For combined treatments, UA and VEPS 1:1, or UA and APS 1:1 were applied and incubated for 24,48 and $72 \mathrm{~h}$, respectively, at $37^{\circ} \mathrm{C}$.

Cell viability/proliferation assay. HepG2 cells were plated at $5 \times 10^{3}$ cells/well in 96-well plates, and incubated with varying concentrations of UA, VEPS and APS at different time points. The MTT solution was added to the culture medium at a final concentration of $0.5 \mathrm{mg} / \mathrm{ml}$ for $4 \mathrm{~h}$, and dark blue formazan crystals were dissolved with $150 \mu \mathrm{l}$ DMSO. The absorbance value was measured at $570 \mathrm{~nm}$ using a multiwell spectrophotometer (Bio-Rad, Hercules, CA, USA). Experiments were performed in quadruplicate and repeated three times. The percentage of cell inhibition was calculated using the formula: inhibitory rate $(\%)=\left[1-\left(\right.\right.$ absorbance $\left._{\text {experiment well }}\right) /\left(\right.$ absorbance $\left.\left._{\text {control well }}\right)\right] \times 100$.

Observations of apoptosis morphology using a scanning electronic microscope (SEM). HepG2 cells $\left(1 \times 10^{5}\right.$ cells/ well) were grown on cover slips in 6-well plates in a $\mathrm{CO}_{2}$ incubator, then treated with UA $(5 \mu \mathrm{g} / \mathrm{ml})$, VEPS $(50 \mu \mathrm{g} / \mathrm{ml})$, APS $(50 \mu \mathrm{g} / \mathrm{ml})$, UA/VEPS 1:1 in combination, or UA and APS 1:1 in combination. After $48 \mathrm{~h}$, the cells were washed with PBS three times, and subsequently fixed for $2 \mathrm{~h}$ at $4^{\circ} \mathrm{C}$ with $2.5 \%$ glutaraldehyde in $0.2 \mathrm{M}$ cacodylate buffer, $\mathrm{pH}$ 7.4. Dehydration was performed with gradients of $30,50,70,90$ and $100 \%$ ethanol, at 10 -min intervals. HepG2 cell surfaces were coated with a gold spray and examined by SEM (Su1510, Hitachi, Japan). Images were collected in TIFF files (PC-SeM, Hitachi) and edited using Photoshop; no artifacts were added.

Flow cytometric analysis. HepG2 cells $\left(1 \times 10^{6}\right.$ cells $\left./ \mathrm{ml}\right)$ were treated with varying concentrations of UA $(5 \mu \mathrm{g} / \mathrm{ml})$, VEPS $(50 \mu \mathrm{g} / \mathrm{ml})$, APS $(50 \mu \mathrm{g} / \mathrm{ml})$, UA/VEPS 1:1 in combination, and UA/APS 1:1 in combination during the exponential growth phase. Cells were collected after being cultured for $48 \mathrm{~h}$. Collected cells were washed twice with cold PBS, fixed with $70 \%$ pre-cooled ethanol, and subsequently incubated overnight in the dark at $4^{\circ} \mathrm{C}$. Cell cycle analysis was performed by flow cytometer (BD Biosciences, Franklin Lakes, NJ, USA).

Determination of intracellular SOD activity. HepG2 cells were plated at $5 \times 10^{3}$ cells/well in 96-well plates, and incubated with varying concentrations of UA, VEPS, APS, combined 1:1 UA and VEPS, or combined 1:1 UA and APS for $48 \mathrm{~h}$. The cells were washed twice with ice-cold PBS, lysed for $10 \mathrm{~min}$ in lysis buffer, and centrifuged for $5 \mathrm{~min}$ at $1,400 \mathrm{x}$ g. Cellular SOD activity was measured in non-protein cell lysates using a commercially available SOD assay kit according to the manufacturer's instructions.

Determination of intracelluar MDA content. HepG2 cells were plated at $5 \times 10^{3}$ cells/well in $96-$-well plates, and incubated with different concentrations of UA, VEPS, APS, combined 1:1 UA and VEPS, or combined 1:1 UA and APS for $48 \mathrm{~h}$. The cells were washed twice with ice-cold PBS, lysed for $10 \mathrm{~min}$ in lysis buffer, and centrifuged for $5 \mathrm{~min}$ at 1,400 x g. Cellular 
MDA content was measured in non-protein cell lysates using a commercially available MDA assay kit according to the manufacturer's instructions.

Reverse-transcription polymerase chain reaction (RT-PCR). After HepG2 cells were exposed for $48 \mathrm{~h}$ to $5 \mu \mathrm{g} / \mathrm{ml}$ of UA, $50 \mu \mathrm{g} / \mathrm{ml}$ of VEPS, $50 \mu \mathrm{g} / \mathrm{ml}$ APS, combined 1:1 UA and VEPS, or combined 1:1 UA and APS, total RNA was extracted from the cells using RNeasy Mini kit. First strand cDNA was generated via reverse transcription of $2 \mu \mathrm{g}$ of the total RNA using a RevertAid First Strand cDNA Synthesis kit (Fermentas, USA). The standard PCR conditions for COX-2 were: $94^{\circ} \mathrm{C}$ for $4 \mathrm{~min}$, then 30 cycles at $94^{\circ} \mathrm{C}$ for $45 \mathrm{sec}, 56^{\circ} \mathrm{C}$ for $45 \mathrm{sec}$ and $72^{\circ} \mathrm{C}$ for $1 \mathrm{~min}$, followed by $10 \mathrm{~min}$ at $72^{\circ} \mathrm{C}$. $\beta$-actin, a housekeeping gene, was selected as an internal standard to account for variability in amplification due to differences in the starting mRNA concentrations. The PCR conditions were as follows: $94^{\circ} \mathrm{C}$ for $3 \mathrm{~min}$, then 35 cycles at $94^{\circ} \mathrm{C}$ for $30 \mathrm{sec}, 57^{\circ} \mathrm{C}$ for $45 \mathrm{sec}$ and $72^{\circ} \mathrm{C}$ for $30 \mathrm{sec}$, followed by $10 \mathrm{~min}$ at $72^{\circ} \mathrm{C}$. The correct fragment of PCR was confirmed by a commercial sequencing service company (BGI, Beijing, China). Primer sequences for COX-2 and $\beta$-actin are listed in Table I.

COX-2 expression by western blotting. HepG2 cells were incubated with $5 \mu \mathrm{g} / \mathrm{ml} \mathrm{UA}, 50 \mu \mathrm{g} / \mathrm{ml}$ VEPS, $50 \mu \mathrm{g} / \mathrm{ml}$ APS, combined 1:1 UA and VEPS, or combined 1:1 UA and APS for $48 \mathrm{~h}$. Cells were collected and washed twice with ice-cold PBS. Lysates were incubated for $10 \mathrm{~min}$ on ice, sonicated and centrifuged for $15 \mathrm{~min}$ at $12,000 \mathrm{x} \mathrm{g}$. After protein concentrations were determined using the Bradford assay, the samples were boiled for $10 \mathrm{~min}$, equal amounts of protein (20 $\mu$ l/lane) were separated by SDS-PAGE, transferred to nitrocellulose membranes, and immunoblotted with a 1:1000 dilution of primary antibody against COX-2 and 1:4000 dilution of primary antibody against $\beta$-actin at $4{ }^{\circ} \mathrm{C}$ overnight. The secondary antibody was goat anti-rabbit $\mathrm{IgG}$ antibody $(\mathrm{H}+\mathrm{L})$ diluted 1:5,000 in blocking solution for $1 \mathrm{~h}$ at room temperature. Immunoreactivity was detected using West Pico Mouse IgG Detection kit and visualized by autoradiography.

Measurement of intracellular COX-2 by ELISA. HepG2 cells were plated at $5 \times 10^{3}$ cells/well in 96-well plates, and incubated with varying concentrations of UA, VEPS, APS, combined 1:1 UA and VEPS, or combined 1:1 UA and APS for $48 \mathrm{~h}$. Cells were washed twice with ice-cold PBS and lysed for $10 \mathrm{~min}$ in lysis buffer. COX-2 concentration was measured in plates coated with purified human COX-2 antibody, using a commercially available human COX-2 ELISA kit, according to the manufacturer's instructions.

Measurement of PGE2 levels by ELISA. HepG2 cells were plated at $5 \times 10^{3}$ cells/well in 96-well plates, and incubated with varying concentrations of UA, VEPS, APS, combined 1:1 UA and VEPS, or combined 1:1 UA and APS for $48 \mathrm{~h}$. PGE2 levels in the culture media were analyzed in plates coated with purified human PGE2 antibody, using a commercially available human PGE2 ELISA kit, according to the manufacturer's instructions.

Statistical analysis. Data are reported as the means \pm SD. Statistical analyses used analysis of variance (ANOVA) tests.

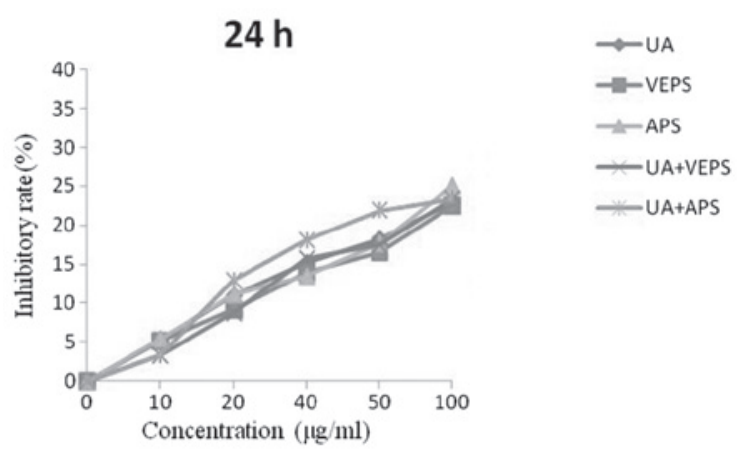

$48 \mathrm{~h}$

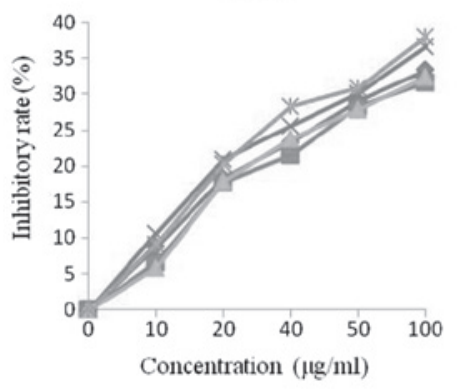

$72 \mathrm{~h}$

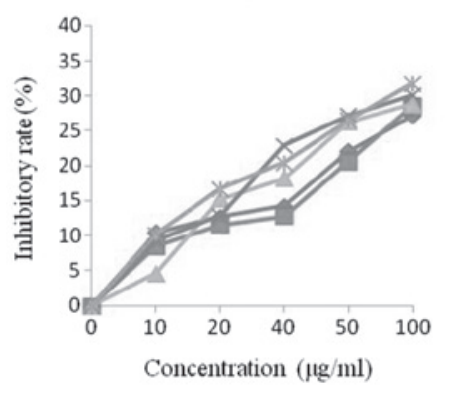

Figure 1. Inhibitory effect of different compounds on HepG2 cell proliferation. HepG2 cells were incubated at different concentration of UA $(0.1,1,2.5$, 5 , or $10 \mu \mathrm{g} / \mathrm{ml})$, VEPS/APS $(10,20,40,50$, or $100 \mu \mathrm{g} / \mathrm{ml})$, or combined treatments for different time periods $(24,48$, or $72 \mathrm{~h})$. UA, ursolic acid; VEPS, viili exopolysaccharides; APS, Astragalus polysaccharide.

Differences among means were determined by the least significance difference test. $\mathrm{P}<0.05$ was considered to indicate a statistically significant difference.

\section{Results}

UA, VEPS, APS and combined treatments inhibited HepG2 cell proliferation. UA, VEPS, APS and combination treatments induced HepG2 cell deaths in a time- and dose-dependent manner (Fig. 1). Incubation with varying doses of UA, VEPS, APS and combined treatments for different time periods $(24,48$, or $72 \mathrm{~h}$ ) resulted in the significant inhibition of cell proliferation $(\mathrm{P}<0.05)$. However, inhibition at $48 \mathrm{~h}$ was stronger than that at $24 \mathrm{~h}$ or $72 \mathrm{~h}(\mathrm{P}<0.05)$. Furthermore, there was greater inhibition by the combined treatments than with individual treatments $(\mathrm{P}<0.05)$.

UA, VEPS, APS and combined treatments induced apoptotic blebs in HepG2 cells. Morphological changes to cells 

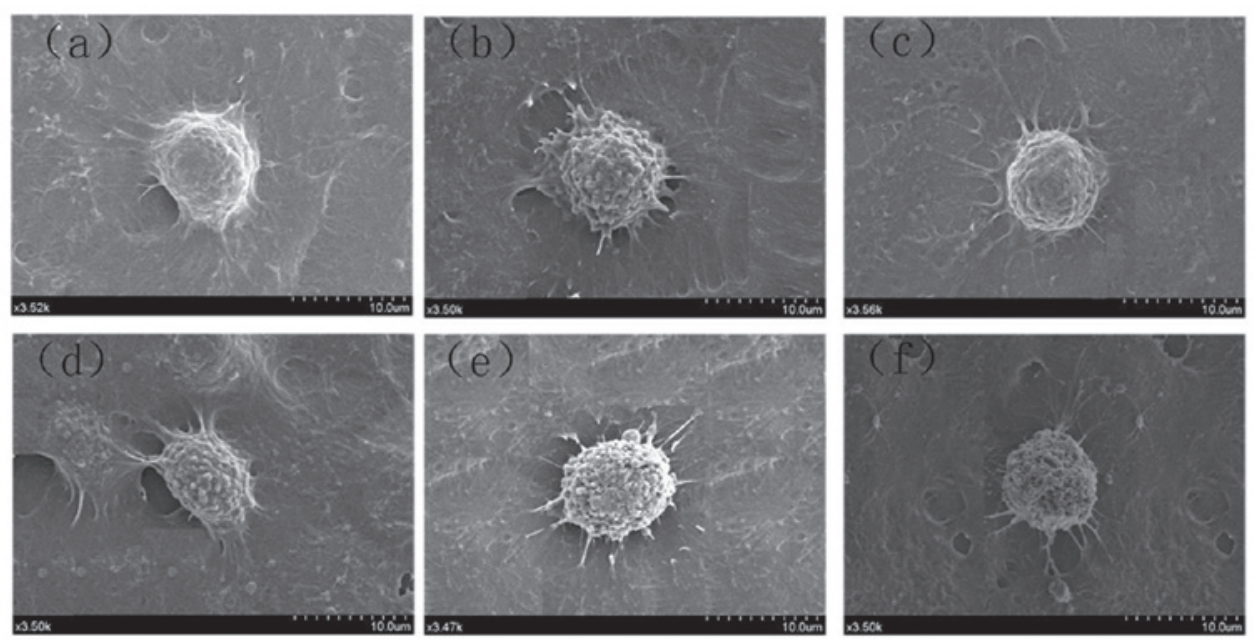

Figure 2. Effects of different compounds on the cell apoptotic morphology. HepG2 cells were treated with UA ( $5 \mu \mathrm{g} / \mathrm{ml}), \mathrm{VEPS}(50 \mu \mathrm{g} / \mathrm{ml}), \mathrm{APS}(50 \mu \mathrm{g} / \mathrm{ml})$ or combined treatments for $48 \mathrm{~h}$. Cells exhibited characteristic ultrastructural apoptotic blebs. (a) Control; (b) UA; (c) VEPS; (d) APS; (e) UA+VEPS; (f) UA+APS Original magnification, x3500. UA, ursolic acid; VEPS, viili exopolysaccharides; APS, Astragalus polysaccharide.

A

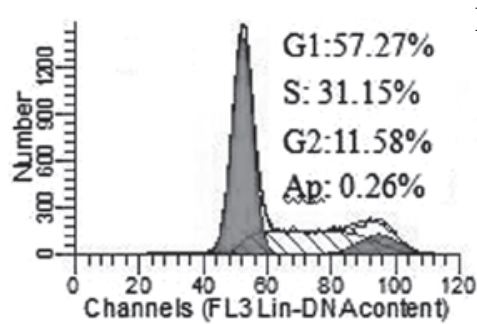

D

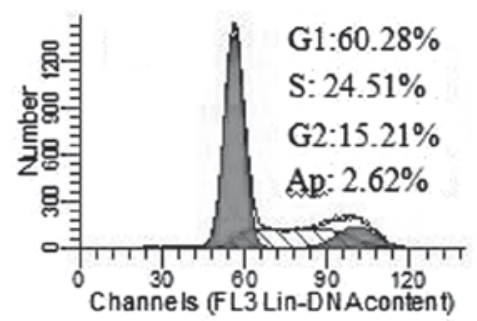

B

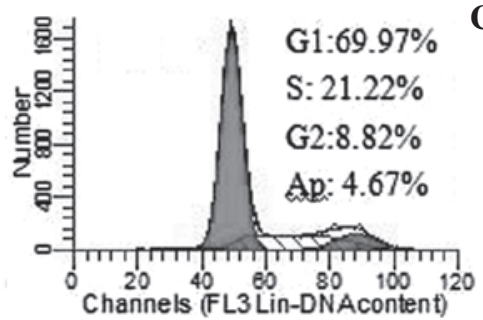

$\mathbf{E}$

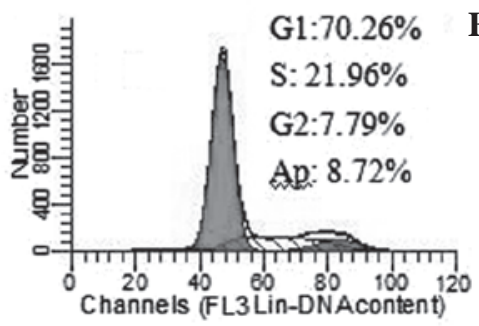

C
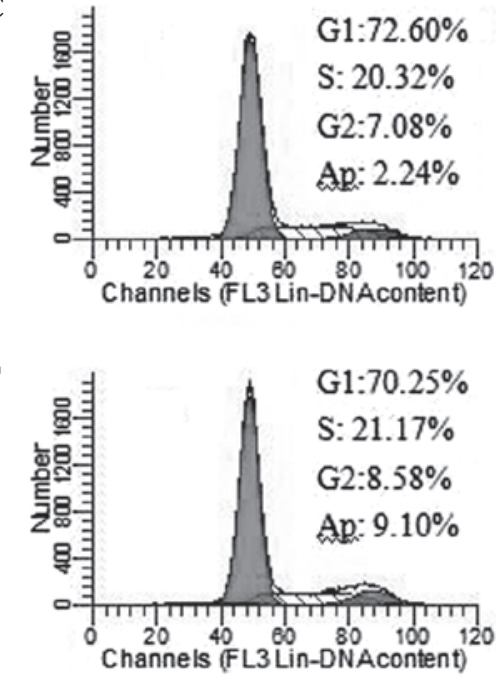

Figure 3. Effects of different compounds on the cell cycle of HepG2 cells. HepG2 cells were treated with UA ( $5 \mu \mathrm{g} / \mathrm{ml}), \mathrm{VEPS}(50 \mu \mathrm{g} / \mathrm{ml}), \mathrm{APS}(50 \mu \mathrm{g} / \mathrm{ml}) \mathrm{or}$ combined treatments for 48 h. (a) Control, (b) UA, (c) VEPS, (d) APS, (e) UA+VEPS and (f) UA+APS. UA, ursolic acid; VEPS, viili exopolysaccharides; APS, Astragalus polysaccharide.

following exposure to UA $(5 \mu \mathrm{g} / \mathrm{ml})$, VEPS $(50 \mu \mathrm{g} / \mathrm{ml})$, APS $(50 \mu \mathrm{g} / \mathrm{ml})$, and combined treatments for $48 \mathrm{~h}$ were visualized under a SEM (Fig. 2). Following treatment with UA, VEPS, or APS, HepG2 cells demonstrated characteristic apoptotic features, with shrinkage, nuclear condensation and DNA fragmentation.

$U A, V E P S, A P S$ and combined treatments increased cell arrest in the HepG2 cell cycle. Following the exposure of HepG2 cells to UA $(5 \mu \mathrm{g} / \mathrm{ml})$, VEPS $(50 \mu \mathrm{g} / \mathrm{ml})$, APS $(50 \mu \mathrm{g} / \mathrm{ml})$, and combined treatments for $48 \mathrm{~h}$, the cell cycle and apoptosis were monitored by flow cytometry (Fig. 3). The percentage of cells increased in the G1- and S-phases. A sub-G1 peak (apoptosis peak) was also observed. Cell apoptosis increased when HepG2 cells were treated with UA and combined compounds. The results indicate that UA, VEPS and APS are capable of inducing cell cycle arrest.
UA, VEPS, APS and combined treatments reduced intracellular ROS activity. SOD is a critical antioxidant enzyme that cleans up cytosolic ROS efficiently. As the drug concentrations increased, SOD activity was significantly downregulated in HepG2 cells (Fig. 4; $\mathrm{P}<0.05$ ). SOD activity was markedly affected at concentrations of $5 \mu \mathrm{g} / \mathrm{ml} \mathrm{UA,} 50 \mu \mathrm{g} / \mathrm{ml}$ VEPS, $50 \mu \mathrm{g} / \mathrm{ml}$ APS and by the combined treatments $(\mathrm{P}<0.01)$. Similarly, MDA is an indicator for intracellular ROS, as the accumulation of MDA is normally increased in cancer cells. Results of our assay showed that the MDA content increased at a low concentration, but decreased at a high concentration of VEPS and APS in HepG2 cells (Fig. 5, P<0.05), However, MDA content was significantly decreased by UA from 0.1 to $10 \mu \mathrm{g} / \mathrm{ml}$, and when combined with 40, 50 and $100 \mu \mathrm{g} / \mathrm{ml}$ VEPS and APS (P<0.01), respectively.

UA, VEPS, APS and combined treatments reduced COX-2 expression in HepG2 cells. RT-PCR analysis results (Fig. 6A, 
Table II. Inhibitory effects of different compounds on cyclooxygenase (COX)-2 concentration in HepG2 cells at 48 h.

COX-2 concentration

\begin{tabular}{lcccccc}
\cline { 2 - 6 } Samples & $0(\mu \mathrm{g} / \mathrm{ml})$ & $10(\mu \mathrm{g} / \mathrm{ml})$ & $20(\mu \mathrm{g} / \mathrm{ml})$ & $40(\mu \mathrm{g} / \mathrm{ml})$ & $50(\mu \mathrm{g} / \mathrm{ml})$ & $100(\mu \mathrm{g} / \mathrm{ml})$ \\
\hline UA & $11.10 \pm 0.66$ & $8.63 \pm 0.47$ & $8.75 \pm 1.45$ & $6.90 \pm 0.72$ & $4.33 \pm 0.20^{\mathrm{b}}$ & $5.49 \pm 1.13^{\mathrm{a}}$ \\
VEPS & $11.10 \pm 0.66$ & $9.51 \pm 0.58$ & $7.94 \pm 1.01$ & $6.62 \pm 0.31$ & $5.73 \pm 0.47^{\mathrm{a}}$ & $6.22 \pm 0.98$ \\
APS & $11.10 \pm 0.66$ & $9.47 \pm 0.87$ & $8.95 \pm 1.95$ & $8.01 \pm 0.69$ & $5.59 \pm 0.94^{\mathrm{a}}$ & $6.08 \pm 1.56$ \\
UA+VEPS & $11.10 \pm 0.66$ & $7.39 \pm 0.25$ & $8.11 \pm 0.85$ & $5.77 \pm 0.55$ & $4.65 \pm 0.69^{\mathrm{b}}$ & $5.27 \pm 1.67^{\mathrm{a}}$ \\
UA+APS & $11.10 \pm 0.66$ & $7.90 \pm 0.94$ & $8.82 \pm 0.40$ & $6.45 \pm 1.51$ & $4.81 \pm 0.55^{\mathrm{b}}$ & $5.37 \pm 0.49^{\mathrm{a}}$ \\
\hline
\end{tabular}

A standard curve with absorbance value on the vertical ( $y$ ) axis and concentration on the horizontal ( $x$ ) axis: $y=0.0342 x+0.0148 ; R^{2}=0.9989$. The corresponding concentration of COX-2 in the table was from the standard curve. ${ }^{\mathrm{a}} \mathrm{P}<0.05$; ${ }^{\mathrm{b}} \mathrm{P}<0.01$, compared with the control group. UA, ursolic acid; VEPS, viili exopolysaccharides; APS, Astragalus polysaccharide.

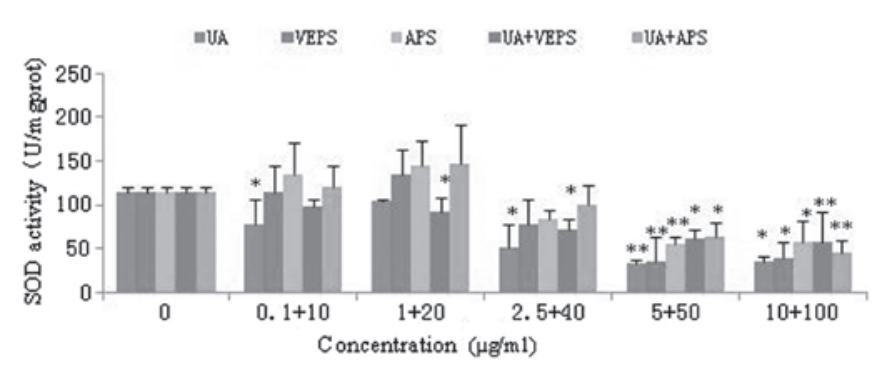

Figure 4. Effects of different compounds on SOD activity in HepG2 cells. HepG2 cells were treated with various doses of UA $(0.1,1,2.5,5$, or $10 \mu \mathrm{g} / \mathrm{ml})$, VEPS/APS $(10,20,40,50$, or $100 \mu \mathrm{g} / \mathrm{ml})$, or combined treatments for $48 \mathrm{~h}$. ${ }^{*} \mathrm{P}<0.05,{ }^{* *} \mathrm{P}<0.01$, compared with control group. SOD, superoxide dismutase; UA, ursolic acid; VEPS, viili exopolysaccharides; APS, Astragalus polysaccharide.

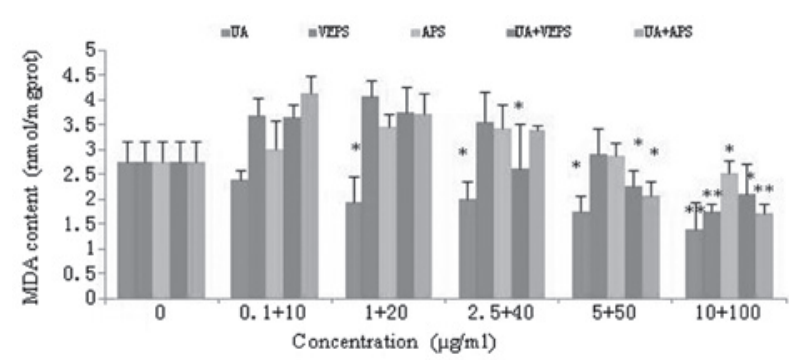

Figure 5. Effects of different compounds on MDA content in HepG2 cells. HepG2 cells were treated with different doses of UA $(0.1,1,2.5,5$, or $10 \mu \mathrm{g} / \mathrm{ml})$, VEPS/APS $(10,20,40,50$, or $100 \mu \mathrm{g} / \mathrm{ml})$, or combined treatments for $48 \mathrm{~h}$. "P $<0.05,{ }^{, * *} \mathrm{P}<0.01$, compared with the control group. MDA, malondialdehyde; UA, ursolic acid; VEPS, viili exopolysaccharides; APS, Astragalus polysaccharide.

$\mathrm{P}<0.05)$ revealed that COX-2 mRNA expression in HepG2 cells was higher in the control group, and downregulated by various compounds (Fig. 6B, $\mathrm{P}<0.05$ ). For HepG2 cells treated with $5 \mu \mathrm{g} / \mathrm{ml}$ of UA, COX-2 mRNA expression was markedly downregulated compared with the controls $(\mathrm{P}<0.05)$, and COX-2 mRNA expression decreased further when treated with combinations of UA and VEPS or APS compared with $50 \mu \mathrm{g} / \mathrm{ml}$ of VEPS or APS alone, compared with the controls $(\mathrm{P}<0.05)$. Western blotting results (Fig. 6C) revealed that COX-2 protein expression was higher in the control compared
A
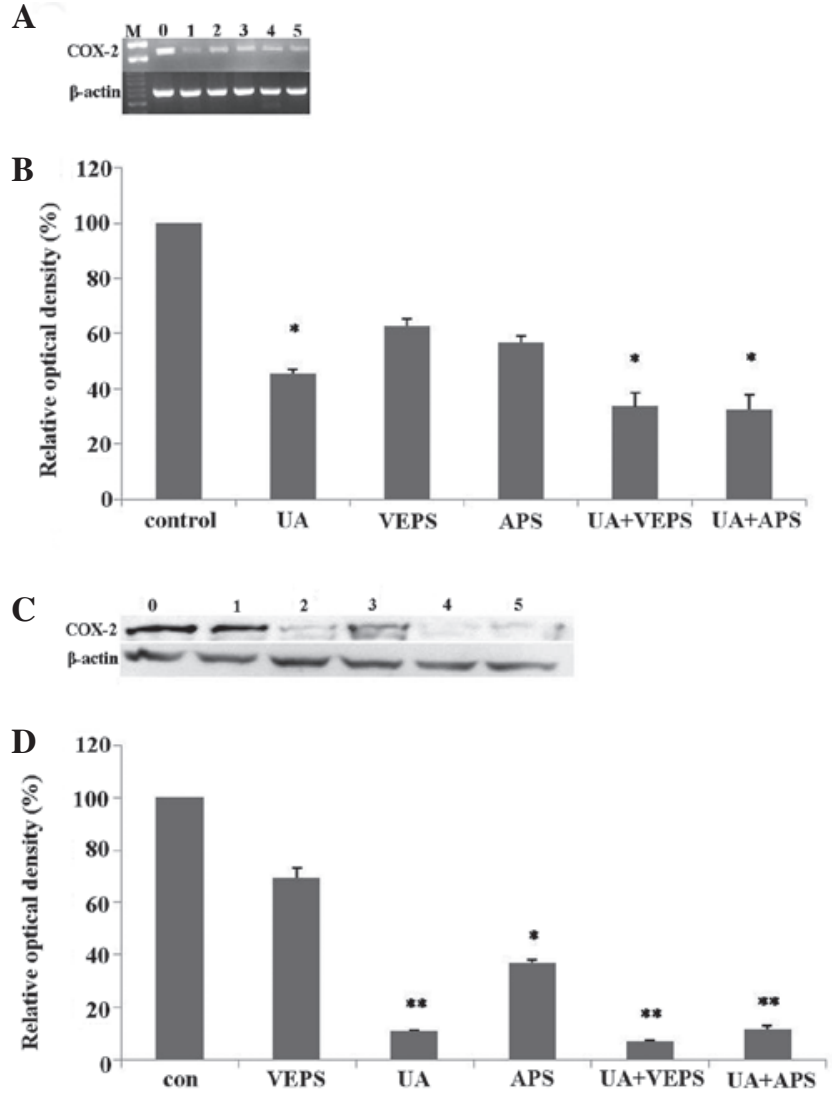

Figure 6. Inhibitory effects of different compounds on (COX)-2 expression in HepG2 cells. HepG2 cells were treated with doses of UA $(5 \mu \mathrm{g} / \mathrm{ml})$, VEPS $(50 \mu \mathrm{g} / \mathrm{ml})$, APS $(50 \mu \mathrm{g} / \mathrm{ml})$ or combined treatments for $48 \mathrm{~h}$. (A) RT-PCR analysis of COX-2 genes. Lane 0 , control; lane 1 , UA $(5 \mu \mathrm{g} / \mathrm{ml})$; lane 2 , VEPS $(50 \mu \mathrm{g} / \mathrm{ml})$; lane 3, APS $(50 \mu \mathrm{g} / \mathrm{ml})$, lane 4, UA+VEPS; lane 5, UA+APS for 48 h. (B) Quantitative analysis of protein levels. ${ }^{*} \mathrm{P}<0.05,{ }^{* *} \mathrm{P}<0.01$, compared with control group. (C) Western blot analysis of protein. Lane 0, control; lane 1 , VEPS $(50 \mu \mathrm{g} / \mathrm{ml})$; lane 2 , UA $(5 \mu \mathrm{g} / \mathrm{ml})$; lane 3 , APS $(50 \mu \mathrm{g} / \mathrm{ml})$, lane 4, UA+VEPS; lane 5, UA+APS for $48 \mathrm{~h}$. (D) Quantitative analysis of protein levels. ${ }^{*} \mathrm{P}<0.05$ compared with control group. COX-2, cyclooxygenase-2; RT-PCR, reverse-transcription polymerase chain reaction; UA, ursolic acid; VEPS, viili exopolysaccharides; APS, Astragalus polysaccharide.

with the experimental groups (Fig. 6D). Additionally, COX-2 protein expression following treatment with $5 \mu \mathrm{g} / \mathrm{ml}$ UA or either combination of UA and VEPS or APS was markedly 
Table III. Inhibitory effects of different compounds on PGE2 concentration in HepG2 cells at $48 \mathrm{~h}$.

\begin{tabular}{lcccccc}
\hline \multirow{2}{*}{ Samples } & $0(\mu \mathrm{g} / \mathrm{ml})$ & $10(\mu \mathrm{g} / \mathrm{ml})$ & $20(\mu \mathrm{g} / \mathrm{ml})$ & $40(\mu \mathrm{g} / \mathrm{ml})$ & $50(\mu \mathrm{g} / \mathrm{ml})$ & \multirow{2}{*}{$100(\mu \mathrm{g} / \mathrm{ml})$} \\
\cline { 3 - 5 } & $120.67 \pm 7.31$ & $78.10 \pm 16.79$ & $51.44 \pm 10.04$ & $39.13 \pm 5.46$ & $17.85 \pm 3.35^{\mathrm{b}}$ & $21.69 \pm 3.53^{\mathrm{b}}$ \\
UA & $120.67 \pm 7.31$ & $109.13 \pm 6.17$ & $61.69 \pm 7.34$ & $52.46 \pm 8.32$ & $30.67 \pm 6.17$ & $35.28 \pm 11.42$ \\
VEPS & $120.67 \pm 7.31$ & $94.00 \pm 12.66$ & $63.74 \pm 10.01$ & $50.15 \pm 4.80$ & $34.77 \pm 10.85$ & $42.72 \pm 13.08$ \\
APS & $120.67 \pm 7.31$ & $84.00 \pm 8.57$ & $61.95 \pm 7.47$ & $46.56 \pm 6.54$ & $22.21 \pm 5.40^{\mathrm{b}}$ & $28.62 \pm 2.77^{\mathrm{a}}$ \\
UA+VEPS & $120.67 \pm 7.31$ & $88.36 \pm 21.92$ & $58.62 \pm 2.77$ & $37.59 \pm 8.15$ & $18.87 \pm 6.98^{\mathrm{b}}$ & $26.82 \pm 10.04^{\mathrm{a}}$ \\
UA+APS & & & & & &
\end{tabular}

A standard curve with absorbance value on the vertical (y) axis and concentration on the horizontal ( $\mathrm{x}$ ) axis: $\mathrm{y}=0.0013 \mathrm{x}+0.0848 ; \mathrm{R}^{2}=0.9984$. The corresponding concentration of PGE2 in the table was from the standard curve. ${ }^{a} \mathrm{P}<0.05 ;{ }^{b} \mathrm{P}<0.01$, compared with control group. PGE2, prostaglandin E2; UA, ursolic acid; VEPS, viili exopolysaccharides; APS, Astragalus polysaccharide.

reduced, compared with the controls $(\mathrm{P}<0.01)$. However, no clear change was observed in the VEPS group, and reduction with $50 \mu \mathrm{g} / \mathrm{ml}$ of APS was less significant when compared with the controls $(\mathrm{P}<0.05)$.

UA, VEPS, APS and combined treatments reduced COX-2 and PGE2 in HepG2 cells by ELISA. Based on the standard curve, as the concentrations of the different tested compounds increased, the COX-2 concentration decreased (Table II), although the effects varied among these treatments; $5 \mu \mathrm{g} / \mathrm{ml}$ UA, $50 \mu \mathrm{g} / \mathrm{ml}$ VEPS, $50 \mu \mathrm{g} / \mathrm{ml}$ APS and the combined treatments significantly reduced COX-2 concentration in HepG2 cells compared with the controls $(\mathrm{P}<0.05)$. Similarly, based on the standard PGE2 curve, with increasing concentrations of the various tested compounds, PGE2 production decreased (Table III). Although effects varied among these treatments, 5 and $10 \mu \mathrm{g} / \mathrm{ml}$ UA significantly reduced the PGE2 titer, while the combined treatments; $5 \mu \mathrm{g} / \mathrm{ml}$ UA with $50 \mu \mathrm{g} / \mathrm{ml} \mathrm{VEPS} \mathrm{or}$ with $50 \mu \mathrm{g} / \mathrm{ml}$ APS, significantly reduced the PGE2 concentration in HepG2 cells compared with the controls $(\mathrm{P}<0.01)$. However, the reduction with $50 \mu \mathrm{g} / \mathrm{ml}$ VEPS or APS alone was less significant, compared with the controls $(\mathrm{P}<0.05)$.

\section{Discussion}

Although the occurrence and development of tumors and malignancies are complex, cancer events are not unusual processes. Potentially cancerous cells are constantly produced, but are usually eliminated in a healthy environment. However, carcinogenesis may occur if the body's internal antioxidant or anti-inflammatory environment changes entirely, or the mechanisms that inhibit abnormal cell proliferation disappear. Previous studies have revealed that antioxidation and anti-inflammation may increase the risk of cancer in certain environments $(23,24)$, where antioxidants are over-enriched, due to the internal antioxidative system, or ARE genes, may be triggered, which eventually increase cell proliferation $(25,26)$. Thus an antioxidant environment may not curb cancer, particularly in cancerous organisms, where COX-2 is overexpressed. COX-2, a double-edged molecule, participates in inflammatory and anti-inflammatory processes. As a downstream product of COX-2, PGE2 frequently affects inflammation, and may be further derived into several so-called electrophilic oxo-derivative (EFOX) molecules with short life-cycles that strongly regulate cell proliferation through the Nrf2/keap1/ ARE pathways (27).

In this study we have demonstrated that UA, VEPS, APS and their combined treatments markedly reduced COX-2 expression, and reduced the concentration of PGE2 in HepG2 cells, as shown by RT-PCR, western blot and ELISA analyses. The inhibition of COX-2 in cancer cells may increase oxidative stress due to decreased levels of EFOXs molecules that mediate the gene expression of SOD and other AREs (28). This is due to the fact that the ARE family, including SOD, create an antioxidative and anti-inflammatory protective environment in order to increase cell proliferation (29). Increased MDA levels, metabolic products of fatty acids, also indicate an oxidative environment. UA is a potent antioxidant with multiple functions, which reduced MDA significantly, while the inhibition of MDA and cell proliferation occurred only with a high concentration of VEPS and APS. Complications in in vivo metabolism occur when the metabolites of fatty acids accumulate. However, it is possible to ignore MDA as it minimizes the metabolism of fatty acids in vitro. Thus it is possible that the inhibition of HepG 2 cell proliferation by UA, VEPS, APS and the combined treatments may be attributed to the inhibition of COX-2 and the associated decreases in SOD activity, which increase the oxidative environment and induce apoptosis, as shown by the higher rate of apoptotic blebs which were observed under the SEM, and the cell-cycle arrest detected by flow cytometry.

These compounds, particularly VEPS, may also have cancer-preventive roles in vivo through the innate immune system (30-32), as VEPS are capable of activating macrophages and lymphocytes without causing severe inflammation or other diseases, and a correlation between its dietary use and cancer epidemiology has been suggested (33).

In conclusion, this study has demonstrated that UA, VEPS, APS, and their combined treatments inhibit HepG2 cell growth. The mechanism for this inhibition may be through the inhibition of COX-2, which in turn reduces EFOXs that activate the internal anti-oxidative elements, including SOD, thus leading HepG2 cancer cells into an over-oxidative environment, causing apoptosis and retarding cell proliferation. 


\section{Acknowledgements}

This study was supported by an initial fund from Tianjin City Government for the '1000 Talents Plan' program to C.L. The authors would like to thank Dr Changlu Wang, Dr Mianhua Chen and Dr Yurong Wang, of the Tianjin University of Science and Technology for their tireless aid. The authors are also thankful to Dr Wentian Liu, Department of Gastroenterology, Tianjin Medical University's General Hospital, Tianjin, China for his critical comments on the preparation of this manuscript.

\section{References}

1. Lodato F, Mazzella G, Festi D, Azzaroli F, Colecchia A and Roda E: Hepatocellular carcinoma prevention: a worldwide emergence between the opulence of developed countries and the economic constraints of developing nations. World J Gastroenterol 12: 7239-7249, 2006.

2. El-Serag HB: Epidemiology of hepatocellular carcinoma. Clin Liver Dis 5: 87-107, 2001

3. Goodgame B, Shaheen NJ, Galanko J and El-Serag HB: The risk of end stage liver disease and hepatocellular carcinoma among persons infected with hepatitis C virus: publication bias? Am J Gastroenterol 98: 2535-2342, 2003.

4. Simonetti RG, Cammà C, Fiorello F, Politi F, D'Amico G and Pagliaro L: Hepatocellular carcinoma: a worldwide problem and the major risk factors. Dig Dis Sci 36: 962-972, 1991.

5. Liu J: Oleanolic acid and ursolic acid: research perspectives. J Ethnopharmacol 100: 92-94, 2005.

6. Aggarwal BB and Shishodia S: Molecular targets of dietary agents for prevention and therapy of cancer. Biochem Pharmacol 71: 1397-1421, 2006.

7. Hsu YL, Kuo PL and Lin CC: Proliferative inhibition, cellcycle dysregulation, and induction of apoptosis by ursolic acid in human non-small cell lung cancer A549 cells. Life Sci 75 2303-2316, 2004.

8. Choi BM,Park R, Pae HO, et al: Cyclic adenosine monophosphate inhibits ursolic acid-induced apoptosis via activation of protein kinase A in human leukaemic HL-60 cells. Pharmacol Toxicol 86: 53-58, 2000

9. Choi YH, Baek JH, Yoo MA, et al: Induction of apoptosis by ursolic acid through activation of caspases and down-regulation of c-IAPs in human prostate epithelial cells. Int J Oncol 17: 565-571, 2000.

10. Huang MT, Ho CT, Wang ZY, et al: Inhibition of skin tumorigenesis by rosemary and its constituents carnosol and ursolic acid. Cancer Res 54: 701-708, 1994.

11. Nishino H, Nishino A, Takayasu J, et al: Inhibition of the tumor-promoting action of 12-O-tetradecanoylphorbol-13-acetate by some oleanane-type triterpenoid compounds. Cancer Res 48: $5210-5215,1988$

12. Cha HJ, Bae SK, Lee HY, et al: Anti-invasive activity of ursolic acid correlates with the reduced expression of matrix metalloproteinase-9 (MMP-9) in HT1080 human fibrosarcoma cells. Cancer Res 56: 2281-2284, 1996.

13. Saxelin ML, Nurmiaho-Lassila EL, Meriläinen VT and Forsén RI: Ultrastructure and host specificty of bacteriophages of Streptococcus cremoris, Streptococcus lactis subsp. diacetylactis, and Leuconostoc cremoris from Finnish fermented milk 'viili'. Appl Environ Microbiol 52: 771-777, 1986.
14. Liu L, Wu J, Zhang J, et al: A compatibility assay of ursolic acid and foodborne microbial exopolysaccharides by antioxidant power and anti-proliferative properties in hepatocarcinoma cells. J Food Agric Environ 10: 111-114, 2012.

15. Kitazawa $H$, Yamaguchi $T$ and Itoh $T$ : B-cell mitogenic activity of slime products produced from slime-forming, encapsulated Lactococcus lactis ssp. cremoris. J Dairy Sci 75: 2946-2951, 1992.

16. Shao BM, Xu W, Dai H, et al: A study on the immune receptors for polysaccharides from the roots of Astragalus membranaceus, a Chinese medicinal herb. Biochem Biophys Res Commun 320: 1103-1111, 2004.

17. Ross R: Atherosclerosis - an inflammatory disease. N Eng J Med 340: 115-126, 1999.

18. Akhtar M, Cheng Y, Magno RM, et al: Promoter methylation regulates Helicobacter pylori-stimulated cyclooxygenase-2 expression in gastric epithelial cells. Cancer Res 61: 2399-2403, 2001.

19. Kim H, Lim JW and Kim KH: Helicobacter pylori-induced expression of interleukin-8 and cyclooxygenase- 2 in AGS gastric epithelial cells: mediation by NF-kappaB. Scand J Gastroenterol 36: 706-716, 2001.

20. Shariat SF, Kim JH, Ayala GE, et al: Cyclooxygenase-2 is highly expressed in carcinoma in situ and $\mathrm{T} 1$ transitional cell carcinoma of the bladder. J Urol 169: 938-942, 2003.

21. Leng J, Han C, Demetris AJ, et al: Cyclooxygenase-2 promotes hepatocellular carcinoma cell growth through Akt activation: evidence for Akt inhibition in celecoxib-induced apoptosis. Hepatology 38: 756-768, 2003.

22. Baek JY, Hur W, Wang JS, et al: Selective COX-2 inhibitor, NS-398, suppresses cellular proliferation in human hepatocellular carcinoma cell lines via cell cycle arrest. World J Gastroenterol 13: 1175-1181, 2007.

23. Mantovani A, Allavena P, Sica A and Balkwill F: Cancer-related inflammation. Nature 454: 436-444, 2008.

24. Coussens LM and Werb Z: Inflammation and cancer. Nature 420 : 860-867, 2002.

25. Oztürk HS, Karayvaz M, Kaçmaz M, et al: Activities of the enzymes participating in purine and free-radical metabolism in cancerous human colorectal tissues. Cancer Biochem Biophs 16: 157-168, 1998.

26. Eapen CE, Madesh M, Balasubramanian KA, et al: Mucosal mitochondirial function and antioxidation defences in patients with gastric carcinoma. Scand J Gastroenterol 33: 975-981, 1998.

27. Luo C, Urgard E, Vooder T and Metspalu A: The role of COX-2 and Nrf2/ARE in anti-inflammation and antioxidative stress: Ageing and anti-ageing. Med Hypotheses 77: 174-178, 2011.

28. Chen C: COX-2's new role in inflammation. Nat Chem Biol 6: 401-402, 2010

29. Groeger AL, Cipollina C, Cole MP, Woodcock SR, et al: Cyclooxygenase-2 generates anti-inflammatory mediators from omega-3 fatty acids. Nat Chem Biol 6: 433-441, 2010.

30. Kerr JF, Winterford CM and Harmon BV: Apoptosis. Its significance in cancer and cancer therapy. Cancer 73: 2013-2026, 1994.

31. Elstein KH and Zucker RM: Comparison of cellular and nuclear flow-cytometric techniques for discriminating apoptotic subpopulations. Exp Cell Res 211: 322-331, 1994.

32. Lebeer S, Claes IJ, Verhoeven TL, et al: Exopolysaccharides of Lactobacillus rhamnosus GG form a protective shield against innateimmune factors in the intestine. Microb Biotechnol 4: 368-374, 2011.

33. Goodman MT, Wu AH, Tung KH, et al: Association of dairy products, lactose, and calcium with the risk of ovarian cancer. Am J Epidemiol 156: 148-157, 2002. 